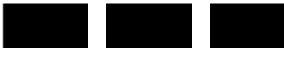 \\ DE
}

The WiLliam DAVIDSON INSTITUTE AT THE UNIVERSITY OF MICHIGAN BUSINESS SCHOOL

The sources of Real Exchange Fluctuations in Developing Countries : an Econometric Investigation

\author{
By: Imed Drine and Christophe Rault
}

William Davidson Institute Working Paper Number 653

February 2004 


\title{
The sources of real exchange fluctuations in developing countries : an econometric investigation
}

\author{
Imed Drine (EUREQua, Sorbonne University ${ }^{1}$ ) \\ Christophe Rault (EPEE, University of Evry-Val D’Essonne ${ }^{2}$ )
}

March 12, 2004

\begin{abstract}
In this paper we address the two following questions: (1) what are the major sources of real exchange rate fluctuations in developing countries? (2) do economic policy makers have room to face possible real exchange rate fluctuations? To answer these questions, we estimate a structural VAR model for 3 developing countries (Morocco, The Philippines, Uruguay) and carry out the conventional exercises of impulse response functions and of variance decomposition of forecast error. Our investigatation suggest that domestic shocks dominate real exchange rate fluctuations and that the contribution of external shocks is relatively low. Besides, the low contribution of the nominal shock put into question monetary policies which seek to promote competitiveness through a currency devaluation. Moreover, our estimations confirm that the real exchange rate also depends on shocks on foreign interest rate and/or on the terms of exchange which can make it move from its equilibrium level. The budgetary tool therefore remains efficient to stabilize the real exchange rate with respect to possible external shocks.
\end{abstract}

Keywords : real exchange rate, developing countries, structural VAR, impulse response functions. JEL Classification: E31, F0, F31, C15.

\footnotetext{
${ }^{1}$ Paris I, Maison des Sciences de l'Economie, 106-112 bd. de L'Hôpital, 75647 Paris Cedex 13, France. E-mail :drine@univ-paris1.fr

${ }^{2}$ Département d'économie, Boulevard François Mitterrand, 91025 Évry Cedex, France. E-mail : chrault@hotmail.com, web-site : http://www.multimania.com/chrault/index.html
} 


\section{Introduction}

Real exchange rate fluctuations have a central place in the discussions over the choices of economic policies in developing economies. Indeed, these fluctuations have some repercussions on the economic performances and strong variations of the real exchange rate entail high economic costs. It is essentially the dependence with respect to imports and the specialization in exports which account for real exchange rate fluctuations on the economic performances of developing countries. The accessibility to the world financial market which helps to smooth out consumption in financing trade balance disequilibrium also plays an important role.

Real exchange rate movements and their relative importance are from a theoretical and empirical point of view one of the major challenges macro-economists and policy makers have to cope with. Indeed, theoretical works confirm that real exchange rate fluctuations depend on the relative importance of different sources of impulsion and that the relationship between the real exchange rate and economic activity is rather complex, particularly for an economy confronted with various shocks.

Previous works, that generally dealt with developed countries, have often focused on domestic shocks and have ignored external shocks as possible sources of fluctuations. However, the importance of external shocks seems obvious for developing countries given their strong dependence with respect to the world economy. A small developing economy differs from a developed one in different ways.

First of all, the exports of developing economies often include products with low added value whose prices are not stable. Having a low power market, developing economies are often confronted with strong fluctuations of their export prices. Besides, a large part of the incomes provided by their exports serves to repay their external debt.

Secondly, developing countries strongly depend on foreign capital and on intermediate inputs imported for their productions. On the basis of these specificities, it is straightforward to conclude that international price fluctuations (primary product prices, intermediate product prices, and foreign interest rate) can have important effects on the cyclic fluctuations and notably on real exchange rate fluctuations ${ }^{3}$.

\footnotetext{
${ }^{3}$ Agnor and Mentiel (1996) analyzed the relationships between international price fluctuations and economic activity
} 
The interest to the analysis of the sources of real exchange rate fluctuations is mainly justified by the central role played by the real exchange rate in developing countries and by the necessity to determine the room economic policy makers have at their disposal to stabilize the exchange rate. Indeed, it is generally admitted that a negative shock of demand (a restrictive budgetary policy) leads to a real exchange rate depreciation whereas a currency offer decrease (a restrictive monetary policy) entails a real exchange rate appreciation. Hence confronted with exogenous variations of the real exchange rate and according to economic policy purposes, the government can react by budgetary and monetary policies. The efficiency of this kind of intervention of course depends on the relative contribution of the shocks on public spending and of nominal shocks (monetary shock and shock on the nominal exchange rate) to real exchange rate fluctuations. Identifying the sources of real exchange rate fluctuations enables to measure, on the one hand, the consequences of economic policies implemented by the government on the real exchange rates, and on the other, the room policy makers have at their disposal to deal with possible real exchange rate movements harmful to economic activity. In this perspective we address in this paper the two following questions:

- what are the major sources of real exchange rate fluctuations in developing countries?

- do economic policy makers have room to face possible real exchange rate fluctuations?

To answer these questions, we estimate a structural Vector Autoregressive Model (VAR) for 3 developing countries (Morocco, The Philippines, Uruguay) and carry out the conventional exercises of impulse response functions and of variance decomposition of forecast error in order to quantify the relative contribution of the different shocks to real exchange rate fluctuations. We assume here the existence of four possible sources of impulsion ${ }^{4}$, namely:

1. domestic real shocks which affect the offer side such as productivity shocks;

2. domestic real shocks which affect the demand side, such as consumption or investment variations, public spending and the shocks on preferences;

in some developing countries and showed that foreign interest rate variations significantly contributed to the cyclic movements. 
3. nominal shocks which reflect the relative variations of money demand with regard to offer and nominal exchange rate variations;

4. external real shocks, for instance a foreign interest rate variation.

Having in mind the identification problem of the various shocks, we expose in a second section a theoretical model which will be used afterwards as a benchmark to specify the dynamics of the various variables with respect to the four shocks.

In a third section, we present the econometric methodology as well as the identification scheme of the shocks. More precisely, the econometric investigation of the sources of real exchange rate fluctuations is carried out in a structural VAR model composed of four variables (production, prices, real exchange rate and foreign interest rate), which respects three theoretical constraints deduced from the previous theoretical model. The originality of our study is that we deal with 3 developing countries (Morocco, the Philippines, Uruguay) ${ }^{5}$ and that we take external shocks as possible sources of real exchange rate fluctuations into account in addition to domestic shocks. We use quarterly data covering the 1979:1 to 1998:1 period.

The fourth section deals with the econometric evaluation of the relative importance of domestic and foreign interest rate shocks to economic and real exchange rate fluctuations, as well as to the economic interpretation and the comparison of our result to previous works. A final section synthesizes our findings and concludes about the sources of real exchange rate fluctuations in developing countries.

\section{The theoretical model of a small open economy}

This section presents a simple theoretical benchmark model inspired by Hoffmaister and Roldos (1997), that clarifies the long-run determinants of our variables of interest. Some economic constraints deduced from this model will be used in the third section to specify the

\footnotetext{
${ }^{4}$ These shocks are classified according to two criteria: domestic-foreign and permanent-transitory.

${ }^{5}$ Let us notice that in order minimize the distortions related to regime changes, our empirical investigation has been limited to the countries for which econometric tests confirmed the absence of significant breaks in the data. This has led us to keep only 3 countries (Morocco, the Philippines, Uruguay) to analyze the dynamic relationships among our 4 variables, whereas our initial database contained 7 developing countries (Korea, Malaysia, Morocco, Mexico, the
} 
identification scheme of the four structural shocks (external shock, offer and demand shocks, nominal shock). These economic constraints will entail restrictions on the long-run parameters of the VAR model. Consequently, the short-run dynamic which is often subject to controversies will not be constrained here, but will be completely determined by data.

The economy produces tradable and non-tradable goods. The tradable sector requires capital $(K)$ and labour $\left(L_{e}\right)$ to produce a quantity of output defined by:

$$
Q_{e t}=Y_{e t}=A_{e t} K_{t}^{1-\alpha} L_{e t}^{\alpha}
$$

where $A_{e}$ represents the technological level of the sector and $t$ denotes time.

The production of non-tradable goods is assumed to require only labour $\left(L_{n}\right)$ and is defined as follows: :

$$
Q_{n t}=Y_{n t}=A_{n t} L_{n t}^{\beta}
$$

Although this specification of the non-tradable goods production technology is somehow restrictive, it permits to reproduce both the labour intensity which is relatively higher with regard to the tradable sector and the low contents in intermediate goods.

The total output expressed in terms of tradable goods of the economy is given by:

$$
Y_{t}=Y_{e t}+p_{t} Y_{n t}
$$

where, $p_{t}$ is the relative price of the non-tradable goods in terms of tradable ones, which represents for us the real exchange rate.

Philippines, Tunisia, Uruguay). 
The equilibrium on the labour market allows us to determine the following relationship between the labour productivity ratio of the two sectors and the real exchange rate, that is :

$$
p=\frac{\alpha A_{e} l_{e}^{\alpha-1}}{\beta A_{n}\left(L-l_{e} K\right)^{\beta-1}}
$$

where $l_{e}=L_{e} / K$ and $\mathrm{L}$ denote respectively the opposite of the per capita capital in the tradable sector and the labour total offer in the economy.

Private agents have access to the international capital market where they can borrow a quantity $D$ at the world interest rate $r^{*}$. At the stationary state the stock of foreign assets is constant, which implies the following equilibrium relationship:

$$
Y_{e}-r^{*} D=C_{e}
$$

where $C_{e}$ is the tradable goods consumption.

At the equilibrium, tradable goods production excluding debt services is equal to the consumption of tradable ones.

Perfect capital mobility at the world level permits to equalize capital marginal productivity to the world interest rate, that is:

$$
(1-\alpha) A_{e} l_{e}^{\alpha}=r^{*}
$$

An increase of foreign interest rate will have a downward effect on production since it will entail a capital flight and hence a decrease in tradable goods production.

To take demand shocks into account we assume that public spending only concerns tradable goods; Hence equilibrium on the non-tradable goods market implies that:

$$
C_{n}=Y_{n}(1-g)
$$

where $C_{n}$ and $\mathrm{g}$ denote respectively non-tradable goods private consumption and the share of public consumptions in the non-tradable goods global output. 
In this model the effect of a fiscal policy is to modify the composition of demand and production in favour of non-tradable goods, with an ambiguous effect on global output. We assume that the long-run effect of an expansionist fiscal policy on the output is low and is not significantly different from zero ${ }^{6}$.

If we denote by $s_{n}$, the share of non-tradable production in total output, and by $\lambda_{n}$ the share of labour in the non-tradable sector, the logarithmic expression of total output is given by:

$$
y_{t}=\Omega+a_{e t}+\left(\alpha-s_{n} / \lambda_{n}\right) \log \left(l_{e}\right)+\left(1-s_{n} / \lambda_{n}\right) \log \left(K_{t}\right)
$$

This equation enables us to determine the factors which are likely to affect output in the long run. A technological shock in the tradable sector leads to a tradable production increase and entails a rise in total output. A positive shock on the interest rate leads to a capital flight and hence to a production decrease.

The real exchange rate equilibrium level can be expressed as :

$$
q_{t}=\Omega_{q}+a_{e t}-a_{n t}+(1-\beta)\left(\left(1-\lambda_{n}\right) / \lambda_{n}\right) \log \left(K_{t}\right)-\left((1-\alpha)-(1-\beta)\left(\left(1-\lambda_{n}\right) / \lambda_{n}\right) \log \left(l_{e}\right)\right.
$$

A positive offer shock resulting from a technical progress in the tradable sector entails a real exchange rate appreciation. The positive wealth effect which accompanies productivity earnings leads to an increase in the non-tradable goods demand and hence to a rise in the nontradable goods relative price. The excess of non-tradable goods demand entails a labour reallocation towards the non-tradable sector and hence an offer increase. A public spending rise also entails a real exchange rate appreciation, public spending being generally largely composed of non-exchangeable goods. An expansionist fiscal policy leads to a labour factor reallocation towards the non-tradable sector, and the equilibrium on the capital markets will be maintained by a decrease of the capital stock. An increase of the foreign interest rate entails a capital flight, and hence a labour productivity decrease in the tradable sector; the real exchange rate will tend to depreciate.

\footnotetext{
${ }^{6}$ Blanchard and Quah (1989) showed that identifying public-spending shock as the one that has no long-run effect on output is robust if its long-run effect is relatively low with regard to that of other shocks.
} 
At the stationary state, the balance of the trade balance can be expressed as follows ${ }^{7}$ :

$$
B C_{t}=\left(Y_{e t}-C_{e t}\right)=\Omega_{b c}+\log \left(r_{t}^{*}\right)+\log \left(K_{t}\right)
$$

A positive shock on the foreign interest rate entails a higher surplus of trade balance. Indeed, the deficit of capital balance induced by a capital flight is compensated by a positive trade balance. A public spending increase leads to a decrease of capital physical stock and hence to a trade balance decrease.

As it is usually done in real business cycle literature, we assume that nominal shocks have no long-run effect on real variables. However, nominal variables are affected in the long run by other real variables. This effect can be passed on through money demand or / and through feedback effects connected to indexation practices and nominal anchoring. To specify better the nature of nominal shocks and to test the relevance of our results we also estimate our model in the econometric part by substituting the nominal exchange rate for the price index.

\section{Econometric methodology and shock identification}

We show in this section that by imposing six long-run restrictions on our VAR model, we can identify the four structural shocks as an external shock, a shock on offer, a shock on demand and a nominal shock. In traditional macroeconomic IS-LM models these shocks can be interpreted as shocks affecting the goods market (movement of the IS curve), shocks affecting the monetary market (movement of the LM curve), shocks on the output capacity and shocks on the world market.

The restrictions imposed on the long-run parameters of the system that we use to identify the structural shocks, are based on the theoretical model presented in the previous section. The basic assumption that we adopt here to differentiate the demand shock from the offer shock is that in the long run output is exclusively determined by offer factors (productivity and foreign interest rate shocks). Hence, we suppose that in the long run output is at its full

\footnotetext{
${ }^{7}$ We hence suppose that at the stationary state domestic physical capital is perfectly substitutable to foreign titles.
} 
employment level and thus only depends on offer factors. However in the short run, given price rigidity, the four sources of impulsion can have an effect on output.

For countries open and strongly dependent on foreign economies a foreign interest rate shock can affect the economy through its effect on the real exchange rate. In particular, a foreign real interest rate increase entails a capital flight and hence an exchange rate depreciation. Furthermore, the negative wealth effect which follows the decrease in the foreign interest rate (decrease in the foreign asset return) entails an expenditure decrease and hence a real exchange rate depreciation (via the non-tradable goods price decrease). To take the indirect effect on the economy into account which can lead to foreign interest rate variations, we do not impose any restrictions on its impact on the real exchange rate.

The external shock is identified as being the only shock that can have a long-run effect on the foreign interest rate. This restriction is justified by the fact that we deal here with small economies whose market power is relatively low on the international. It is important to notice however that the external shock is not the only one that can have an effect on the economy through the exchange rate. For an open economy, the three other shocks can also have an effect via the exchange rate.

In order to differentiate the real shock from the nominal one, we suppose that the latter has no long-run effect on the real exchange rate (Clarida and Gali, 1994). Hence, we suppose that real exchange rate variations are both cyclic movements and permanent deviations to PPA. Nominal shock entails a price increase and a proportional depreciation of the nominal exchange rate. As a result the real exchange rate remains stable in the long-run as predicted by Dornbush and Mundell-Fleming's models.

As the three real shocks can have a permanent effect on the real exchange rate we do not impose restrictions on their long-run effects. In particular, according to the macroeconomic models of an open economy, a positive demand shock entails a real exchange rate appreciation (through price increase). The effect of a positive offer shock on the real exchange rate is on the contrary difficult to predict. On the one hand, productivity increase entails a permanent price decrease and hence a real exchange rate depreciation. On the other, the positive wealth effect which accompanies a productivity shock leads to a non-tradable goods price increase and hence to a real exchange rate appreciation. 


\subsection{Econometric methodology}

To specify the various shocks (external shock, offer and demand shocks, nominal shock) we use here a VAR model composed of four variables (foreign interest rate, GDP, the real exchange rate and prices) taken in first differences ${ }^{8}$.

The economy is hence represented with a vector of four observable series $X_{t}=\left(\Delta r_{t}^{*}, \Delta Y_{t}, \Delta t c r_{t}, \Delta P_{t}\right)$ at every date t, resulting from the dynamic combination of a vector of four past structural shocks $\varepsilon_{t}^{\prime}=\left[\varepsilon_{t}^{r^{*}}, \varepsilon_{t}^{o}, \varepsilon_{t}^{g}, \varepsilon_{t}^{n}\right]$; where $\varepsilon_{t}^{r^{*}}, \varepsilon_{t}^{o}, \varepsilon_{t}^{g}$ et $\varepsilon_{t}^{n}$ denote respectively the external offer, demand and nominal structural shocks.

Let us consider the following model:

$$
\begin{gathered}
X_{t}=\theta+H(0) \varepsilon_{t}+H(1) \varepsilon_{t-1} \cdots \cdots \\
X_{t}=\theta+\sum_{0}^{\infty} H(i) \varepsilon_{t-i}
\end{gathered}
$$

For convenience the expression is rewritten as follows:

$$
X_{t}=\theta+H(L) \varepsilon_{t}
$$

where $\mathrm{L}$ denotes the lag operator and where $\mathrm{H}$ is a $(4 \times 4)$ matrix which determines the dynamics of the four components of the $X_{t}$ vector following exogenous shocks.

The instantaneous effect of $\varepsilon$ on $X$ is given by $\mathrm{H}(0)(\mathrm{i}=0)$; the laged effects of $\varepsilon$ on $X$ are given by $\mathrm{H}(\mathrm{i}), \mathrm{i}>0$. As $X$ is supposed to be stationary, no shock has a long-run effect on the foreign interest rate, the GDP, the real exchange rate and the price rates of variation. On the contrary only external shocks have a long-run effect on the interest rate level, nominal shocks have a long-run effect only on the price level and demand shocks have no long-run effect on the GDP level.

The structural moving average representation (13) has a structural autoregressive representation with $\mathrm{p}$ lags defined as follows:

\footnotetext{
${ }^{8}$ The stationarity of each variable as well as the existence of cointegration relationships among these variables is examined in section 4. It appears that all variables are integrated of order 1 but not cointegrated, which justifies the
} 


$$
B(0) X_{t}=a+B(1) X_{t-1}+\ldots \ldots B(P) X_{t-p}+\varepsilon_{t}
$$

where $\varepsilon_{t}$ is a white noise.

Multiplying each element of (14) by $B(0)^{-1}$, enables to write :

$$
X_{t}=c+A(1) X_{t-1}+\ldots \ldots+A(p) X_{t-p}+u_{t}
$$

$\Longleftrightarrow$

$$
X_{t}=c+\sum_{0}^{\infty} A(i) X_{t-i}+u_{t}
$$

$$
A(L) X_{t}=c+u_{t}
$$

where $A(0)=I$

with $c=B(0)^{-1} a$

$A(i)=B(0)^{-1} B(i)$

and $u_{t}=B(0)^{-1} \varepsilon_{t}$

The VAR Representation given by (17) is the reduced form of the general dynamic model (13). As $\varepsilon_{t}$ is a white noise, it is also the case for $u_{t}$ (since $u_{j t}$ is a linear combination of structural shocks).

Given that the dynamics is stationary, the $u_{t}$ are defined as canonical innovations, that is as the part of $X_{t}$ which cannot be explained linearly by its own history. $u_{t}$ is a white noise with a variance - covariance matrix given by $\mathrm{V}\left(u_{t}\right)=\Sigma$. The vector of canonical innovations $u_{t}$ is defined as: $\hat{u}_{j t}=X_{j t}-\sum_{i=1}^{p} A_{j t} X_{j t 1}, j=1,2,3,4$ (it is the result of the instantaneous combination of structural shocks). At each date t, innovations are estimated as the residuals of regressions corresponding to the estimation of the VAR model. Canonical innovations are the smallest unpredictable parts of the two series at date $t$, given the information relative to the set of the past values of the $X_{t}$ vector at date t. In this sense, they are representative of "surprises" which 
result from "shocks" [Bruneau and De Brandt (1999)].

The moving average representation which corresponds to a Wold decomposition of the dynamics is the result of the inverse function of equation (17), i.e. :

$$
X_{t}=A(L)^{-1}\left(c+u_{t}\right)
$$

$$
X_{t}=d+C(L) u_{t}
$$

with $d=A(L)^{-1} c$ and $A(L)^{-1}=C(L)$

$$
X_{t}=d+\sum_{i=0}^{\infty} C(i) u_{i t}
$$

$$
X_{t}=C(L) u_{t}
$$

where $C(0)=I$.

The responses of two series to innovations are deduced from the dynamic multipliers $\mathrm{C}$.

From (13), (17) and (21), we can notice that:

$$
u_{t}=B(0)^{-1} \varepsilon_{t}=H(0) \varepsilon_{t}=P \varepsilon_{t}
$$

where $\mathrm{P}=\mathrm{H}(0)=\mathrm{B}(0)^{-1}$

$\mathrm{H}(0)$ represents the instantaneous impact of a shock $\varepsilon_{t}$ on $X_{t}$. At each date $\mathrm{t}$ canonical innovations are linear combinations of structural shocks.

From what precedes we obtain the following relations :

$$
\begin{gathered}
X_{t}=H(L) \varepsilon_{t} \\
X_{t}=C(L) u_{t} \\
u_{t}=P \varepsilon_{t}
\end{gathered}
$$


Combining these equations we get :

$$
H(L)=C(L) P
$$

As we can obtain an estimation of C (L) matrix (by inverting the matrix A of the estimated VAR) and an approximation of the $u_{t}$ vector of innovations (with the residuals of the estimated VAR), the knowledge of the $P$ matrix is sufficient to identify both the structural shocks (by multiplying (25) by $\mathrm{P}^{-1}$ ) and the $\mathrm{H}(\mathrm{L})$ matrix which describes the dynamic impact of these shocks on the observable variables (23).

From the residual of the $\Delta r^{*}, \Delta Y_{t}, \Delta t c r_{t}$ and $\Delta P_{t}$ equations we try to identify the four shocks (external, offer, demand and nominal) ${ }^{9}$.

\subsection{Shock identification}

Our aim here is to identify the transformation matrix P. To do so, it is necessary to impose $n \times n$, that is 16 identifying constraints to be able to estimate the simultaneous equation system corresponding to the structural VAR model.

It is usual to suppose that structural shocks $\varepsilon_{t}$ are uncorrelated and have a unitary variance. We impose by this hypothesis alone three bilinear constraints on the elements of the P matrix. Equation (25) implies the following relationship between the variance -covariance matrix of the innovations $\left(\mathrm{V}\left(u_{t}\right)\right.$, and that of structural shocks $\left.\mathrm{V}\left(\varepsilon_{t}\right)\right)$ :

$$
V\left(u_{t}\right)=P V\left(\varepsilon_{t}\right) P^{\prime}
$$

As the two structural shocks are assumed to be uncorrelated, their variance-covariance matrix is unitary $\left(\mathrm{V}\left(\varepsilon_{t}\right)=\mathrm{I}\right)$. Equation $(27)$ can be then rewritten as:

$$
V\left(u_{t}\right)=P P^{\prime}=\Sigma
$$

\footnotetext{
${ }^{9}$ Structural shocks are said to be identified when we can estimate them from the observable series for the considered
} 
The $\mathrm{V}\left(u_{t}\right)$ matrix being symmetric, equation (28) includes $\mathrm{n} \times(\mathrm{n}+1) / 2$ independent non linear constraints on the components of the $\mathrm{P}$ matrix; these ten constraints are of statistical nature $^{10}$.

Six economic constraints remained then to be imposed. Blanchard and Quah (1989) proposed that the identifying constraints concern the short andlor long-run effects of structural shocks on the various components of the system. When the dynamics is stationary, only shortrun constraints can express the absence of instantaneous response to some structural shocks. On the contrary, long-run constraints can only concern the response of a stationary series in first difference and in any case the response of a stationary series [Bruneau and De Brandt (1999)].

In the present case the system is supposed to be stationary in first differences (cf. the results of the econometric part ); We only consider long-run constraints deduced from the previous theoretical model (18). The first constraint implies that internal shocks do not affect the external variable, namely the interest rate. This restriction implies that the external variable should be exogenous and that the accumulated effect of domestic shocks on the interest rate variation is equal in zero. This assumption thus provides us with three additional restrictions. The second restriction implies that nominal shocks do not affect in the long run real variables and that public spending shocks do not affect the output in the long-run. This provides us with the last three constraints. These restrictions can be expressed as follows:

$$
\begin{gathered}
\sum_{i=0}^{\infty} h_{12 i}=\sum_{i=0}^{\infty} h_{13 i}=\sum_{i=0}^{\infty} h_{14 i}=0 \\
\sum_{i=0}^{\infty} h_{23 i}=\sum_{i=0}^{\infty} h_{24 i}=0 \\
\sum_{i=0}^{\infty} h_{34 i}=0
\end{gathered}
$$

\footnotetext{
period.

${ }^{10}$ From an economic point of view these constraints rest upon a strong assumption : there is little reason to think that an offer shock is at each date uncorrelated with a demand shock. "This is probably one of the weakness of the structural VAR methodology" [Bruneau and De Brandt, 1999].
} 
The estimation of the P matrix is made possible by the imposition of 16 constraints (10 statistics and 6 economic ones), what allows to identify the structural shocks and the dynamic impact of these shocks on the observable variables.

It remains to notice that the assumption of an absence of correlation between the shocks and notably between the demand and offer shocks is a strong hypothesis. Let us underline, however, that this assumption does not constrain the canals by which the two shocks affect GDP and the real exchange rate. Besides, it is necessary to note that a demand shock can also have a permanent impact on GDP: variations of the realization rate or changes in fiscal policy can affect the savings rate and hence the product in the long term. Blanchard and Quah (1989) admitted those impacts of demand shocks. However, they postulated that the long-run effects of demand shocks on GDP are low in comparison to the long-run effects of offer shocks. From this postulate, they demonstrated that the identification procedure is "nearly correct" insofar as the procedure used (null effect in the long-run of demand shocks on GDP), is close to the one that should have been used (long-run effect of demand shocks on GDP but whose size is lower than that of offer shocks).

For our analysis, we classify the shocks into 3 categories:

- $\quad$ nominal and real shocks;

- domestic and external shocks;

- $\quad$ permanent and transitory shocks.

Permanent shocks are those which have a permanent effect on the real exchange rate and on output, namely offer shocks, demand ones and external ones (shocks on foreign interest rate). The offer shock, which has a long-run effect on output, can come from a structural change such as an economic liberalization. The relative demand shock can have for origin public spending. Finally, the nominal shock which will only have a long-run effect on prices can be considered as a monetary one. 


\section{The econometric investigation of the sources of real exchange rate fluctuations}

We estimate a first model composed of four variables, namely foreign interest rate, output, the real exchange rate and prices and, a second one where prices are replaced by the nominal exchange rate. The countries chosen for the empirical evaluation are Morocco, the Philippines and Uruguay. We use quarterly data covering the 1979:1 to 1998:1 period. Hence the $\mathrm{X}_{t}$ vector of data analyzed for each of the three countries, is given by :

$$
X_{t}=\left(r_{t}^{*}, Y_{t}, t c r_{t}, P_{t}\right)
$$

where $r_{t}^{*}$ denotes the log of the real interest rate in the USA, $Y_{t}$ the log of GDP, $t c r_{t}:$ the $\log$ of the real exchange rate, and where $\mathrm{P}_{t}$ is the $\log$ of the consumption price index. For some countries we approximate GDP by the manufacturing production given the unavailability of quarterly data for income. We choose the multilateral index expressed as the ratio of domestic and foreign consumption price indices as an indicator of the real exchange rate. The real exchange rate is defined with regard to the main trading partners of each country, and an increase implies an appreciation. The choice of the multilateral exchange rate is justified by the fact that it is the best indicator allowing to give a good picture of the evolution of the external true value of the national currency and economic activity (Bankim and Prasad, 1997). We use the general price index to calculate the real exchange rate. The data are extracted from the Agénor et al (2000) and from the IMF database.

We examine in a first step the univariate properties of macroeconomic series, and we test in a second one the existence of cointegrating relationships between the components of the $X_{t}$ vector for each of the 3 countries.

\subsection{Stochastic properties of data}

In this paragraph we investigate the stochastic properties of each series for the 3 
countries. To determine the most appropriated econometric specification to data properties, it is necessary to test whether the variables are stationary or integrated of order 1 . To do so, we implement the unit-root tests of Kwiatowski, Phillips and Shin (1992), hereafter "KPSS , as well as the efficient test proposed by Elliott, Rothenberg and Stock (1996), hereafter "ERS ". The results of these tests reported in appendix (cf. table 1) clearly indicate that all our macroeconomic series are integrated of order 1, since in most cases, the null hypothesis of unit root cannot be rejected at the $5 \%$ level of significance.

The next stage consists in testing the existence of a cointegrating relationship between the four variables taken in level (for each of the 3 countries). As it is generally recognized, if the variables are cointegrated, a VAR model in first difference is not be the appropriate specification to analyze the sources of impulsions for the different variables, but a VAR-ECM model must be used.

The procedure developed by Johansen and Juselius (1990) allows to test for the number of cointegrating relationships between our system of variables, using the well known following two test statistics: the "trace" and the maximal eigen value tests. For this purpose, the basic representation of the $\mathrm{n}$ dimensional $X_{t}$ vector $\left(X_{t}=A_{t} X_{t}+\ldots \ldots .+A_{k} X_{t-k}+\mu+\varepsilon_{t}\right)$ can easily be rewritten as the above error correction model:

$$
\Delta X_{t}=\Pi_{t} \Delta X_{t-1}+\ldots \ldots .+\Pi_{k+1} \Delta X_{t-k+1}+\Pi \Delta X_{t-k}+\mu+\varepsilon_{t}
$$

with $\Pi=-\left(I-A_{1}-\ldots . .-A_{k}\right)$ and $\Pi_{i}=-\left(A_{i+1}-\ldots-A_{k}\right)$ for $i=1 \ldots . . k$ where $\Delta$ is the differentiation operator. The $\Pi$ represents the long-run dynamics of the $X_{t}$ system of three variable while the $\Pi_{i}$ determines the short-run dynamics. $\varepsilon_{t}$ is a white noise .

The cointegration hypothesis is formulated as the rank (number of independent line vectors ) of the $\Pi$ matrix :

$$
H_{1}(r): \Pi=\alpha \beta
$$

where $\alpha$ and $\beta$ are $(p \times r)$ matrices of rank $r \leq p$, and $\alpha$ the matrix containing the cointegrating vectors ( $r$ being the number of cointegrating relationships and $p$ the number of 
variables).

Since the $H_{1}(r)$ hypothesis implies that the $\Delta X_{t}$ process is stationary and as $X_{t}$ is $I(1)$, then the $\beta^{\prime} X_{t}$ combination is necessarily stationary. The $\beta^{\prime} X_{t}$ matrix contains the long-run relationships between the four variables. The rank of the $\Pi$ matrix determines the number of long-run relationships. More exactly, this $\mathrm{r}$ rank can be investigated using the two following well-known test statistics proposed by Johansen-Juselius-90:

$$
\begin{aligned}
& \text { - } \quad \text { Trace test }=-2 \ln Q\left(H_{1}(r) / H_{0}\right)=-T \sum_{i=r+1}^{3} \ln \left(1-\lambda_{r}\right) \\
& \text { - } \quad \lambda_{\max } \text { test }=-2 \ln Q\left(H_{1}(r-1) / H_{1}(r)\right)=-T \ln \left(1-\lambda_{r}\right)
\end{aligned}
$$

The trace statistic allows to test the null hypothesis that the rank of the matrix is equal to $r$ against the alternative that the rank is $p-1$ and the maximum eigenvalue statistic tests the null hypothesis that the rank of the matrix is $r$ against the alternative that the rank is $r+1$. The asymptotic distributions of these test statistics are non-standard and can be found in Johansen (1988) and Johansen and Juselius (1990). The optimal number of lags to introduce into the model is selected according to a sequential procedure which consists in testing the null hypothesis of $k$ lags against the alternative of $q$ lags, with $q<k$ (the test statistic having in this case a Chi Square distribution with $n \times n \times(k-q)$ degrees of freedom, $\mathrm{n}$ being the number of variables).

For our 3 countries the trace and maximum eigenvalue statistics ${ }^{11}$ both indicate at the $5 \%$ level of significance the absence of a cointegrating relationship between the $r^{*}, Y, t c r$ and $P$ variables over the 1979:1 to 1998:1 period (cf. table 2 in appendix). Consequently, the econometric modelling compatible with the data property is a VAR model for the four variables taken in first differences, for the 3 countries.

\footnotetext{
${ }^{11}$ In this kind of procedure the choice to introduce or not determinist components into the cointegrating vectors is rather complicated. Indeed, the bad specification of the long-run relationship can lead to wrong conclusions on the nature of the dynamic which characterizes the movement of the different variables. Hence, a preliminary exercise consists in identifying the underlying model. In this optics Johansen (1992) developed a sequential procedure to identify the "true" model. The implementation of this procedure has finally led us not to include any determinist component.
} 


\subsection{Stability tests}

One of the most important steps to undertake before proceeding to the examination of the impulse response functions and the variance decomposition of forecast error, is to make sure that the estimated econometric relationship is stable over the period of study. To do so, we have to examine whether the estimated parameters of this relationships are robust or not. Indeed, these parameters may change over time because of economic policy changes (modifications of exchange rate regimes) or because of internal or external economic modifications. However, in some cases economic instability does not entail significant exchange rate regimes altering the nature of the relationship between variables.

To examine the robustness of the relationship between the four variables, we carried out the two well known stability tests proposed by Chow (the1-step test, and the N-step test) and we concluded that the estimated parameters of ou rVAR models are stable over time for Morocco, the Philippines and Uruguay ${ }^{12}$.

\subsection{Impulse response function analysis}

Figure 1 in appendix provides for each of the three countries the impulse response functions of the four variables to the four structural shocks. It depicts the response of each variable taken in level to a $1 \%$ shock as well as the confidence interval ${ }^{13}$. The examination of the impulse response functions enable to evaluate the relevance of the identification scheme. As our variables are expressed in first difference, the analysis of the effects of the different shocks on the variables in level is made on the basis of the accumulated response functions.

\footnotetext{
${ }^{12}$ It is important to emphasise that actually our original database contained 7 developing countries (Korea, Malaysia, Morocco, Mexico, the Philippines, Tunisia, Uruguay). However on the basis of the Chow tests we found that in Tunisa, Malaysia, Korea and Mexico the estimated parameters of the VAR model were subject to strong variations according to the sample period considered. This led us to exclude these countries from our sample and to focus exclusively on Morocco, the Philippines and Uruguay to analyze the dynamic relationships among our 4 variables.

${ }^{13}$ The confidence interval is calculated using the boostrap method.
} 


\subsubsection{The effect of a shock on the foreign interest rate}

According to theoretical expectations a positive shock on the foreign interest rate entails a production decrease and a real exchange rate depreciation. The response of GDP and of the real exchange rate is almost identical in the three countries. Indeed, a foreign interest rate increase leads to a decrease of about $0.1 \%$ of GDP and of the real exchange rate. However, in Uruguay a small instantaneous increase of GDP can be noticed that vanish in the first period; the adjustment to the equilibrium state is however rather slow. Prices increase in Uruguay and in the Philippines; This rise completely disappears at the 13th period in Uruguay. For Morocco, on the contrary the long-run effect of the external shock on prices is negative but not significant. Hence the wealth effect which accompanies the interest rate increase doesn't seem important enough to entail a demand increase.

\subsubsection{The effect of a shock of offer}

The response of the real exchange rate and GDP to a shock of offer confirms theoretical predictions. Indeed, a positive shock of offer entails a GDP increase and a real exchange rate appreciation

- The offer shock affects in the same way all sectors of the economy;

- The offer effect which accompanies the offer shock dominates the wealth effect (demand effect).. We can noticed that the long-run response of GDP is relatively smaller than its short-run response and that adjustment to equilibrium is relatively slower than that of the real exchange rate. A shock of offer of $1 \%$ entails a GDP long-term increase of $0.8 \%$ in Uruguay, $0.6 \%$ in Morocco and $0.9 \%$ in the Philippines ${ }^{14}$. Besides, it seems that the real exchange rate sensibility to a shock of offer is relatively higher in the Philippines than in the other countries: the real exchange rate increases by $0.2 \%$ in the Philippines and only about $0.1 \%$ in Morocco and in Uruguay.

The price response to a shock of offer is a priori ambiguous since it is positive in Uruguay and negative in Morocco and in the Philippines. The price decrease in the Philippines 
and Morocco reflects well the predominance of the direct effect of offer on the effect of demand. However in Uruguay it is the effect of demand that is dominant.

\subsubsection{The effect of a shock of demand}

A positive shock of demand entails a price increase and a real exchange rate appreciation, which confirms that it is effectively a shock of public spending. However, the production decrease in Uruguay and in the Philippines is a priori contradictory to the theoretical predictions and needs consequently to be accounted for ${ }^{15}$. Actually, in the theoretical model explained previously, the long-run effect of a shock of demand on GDP is ambiguous. Two explanations can be proposed. Firstly, as public spending is generally related to non-tradable goods, a public spending increase entails a resource reallocation and a decrease of non-tradable goods offer ${ }^{16}$. Secondly, the expected view of fiscal policy approach predicts the recessionist effect of an expansionist public fiscal policy (see Giavazzi and Pagano, 1990).

Following a positive shock of demand, prices increase and reach their long-run level in about 4 and 20 quarters. Prices seem sticker in Uruguay but their response is relatively higher (2 $\%$ against $0.2 \%$ in the Philippines and $0.4 \%$ in Morocco).

Following a positive shock of demand the real exchange rate appreciates and the adjustment to the equilibrium state is progressive (no overshooting), relatively fast in Morocco and in the Philippines and takes between two and four quarters; adjustment is relatively slower in Uruguay. If we compare the responses of the real exchange rate and prices, we notice that a positive shock of demand also leads to a nominal exchange rate appreciation.

\subsubsection{The effect of a nominal shock}

The effect of a monetary shock on the real exchange rate, the nominal exchange rate and prices is in accordance with theoretical predictions. Indeed, a positive nominal shock entails a

\footnotetext{
${ }^{14}$ Kamin and Roger (1997) obtained a similar result for Mexico.

${ }^{15}$ Hoffmaister and Roldos (2001) obtained a similar result for Brazilian economy.

${ }^{16}$ In our study the GDP is approximated by the industrial production which is composed of tradable goods.
} 
temporary (respectively permanent) depreciation of the real (respectively nominal) exchange rate and a permanent price increase. The price adjustment to a nominal shock is relatively low in Uruguay and takes more than 20 quarters. However, for Morocco and the Philippines, prices take 2 to 4 quarters to reach their long-run level. Furthermore, the response of prices is relatively high in Uruguay, about $3 \%$ whereas it is only $1.5 \%$ in the Philippines and $1.2 \%$ in Morocco.

The temporary depreciation of the real exchange rate is relatively fast in Morocco and in the Philippines and the nominal shock effect vanishes at the 5th quarter. However, in Uruguay the real exchange rate needs more time to go back to its equilibrium level. The real exchange rate adjustment which is relatively slower in Uruguay, is compatible with the price response to a nominal shock. It can also be explained by the fact that in Uruguay the nominal exchange rate is not perfectly correlated to prices as it is the case in Morocco and in the Philippines.

Contrary to the theoretical expectations for a closed economy the GDP response to a positive nominal shock is negative in Uruguay, whereas theoretically it is expected to entail an economic expansion. Actually, the GDP response to a positive nominal shock confirms the idea of the recessionist effect of an exchange rate depreciation (Lizondo and Montiel, 1989).

\subsection{The variance decomposition of forecast error}

The variance decomposition of forecast error enables to determine the most important fluctuation sources of the endogenous variables for the period of study. In particular, the variance decomposition of forecast error permits to measure the part of the anticipated variance of each endogenous variable explained by the different shocks for the different horizons. We calculate the contribution of the external offer, demand and nominal shocks to the variations of the level of each variable ${ }^{17}$. The results are reported in the appendix (cf. tables 3, 4 and 5) for a horizon of 25 quarters.

The variance decomposition of forecast error confirms that for all countries the GDP growth rate is mainly determined by domestic shocks and that the external shock only plays a

\footnotetext{
${ }^{17}$ The variance decomposition of forecast error of the variables taken in first difference can be different from that of the variables in level. In fact, the variance decomposition of forecast error of the variable in level (respectively in first difference) is based on a non-linear transformation of the impulse response functions of the variables in level (respectively in first difference) for the different shocks.
} 
minor role. Indeed, the contribution of domestic shocks to GDP fluctuations is about $98 \%$ for the three countries, both for the short and long-run. Among the domestic shocks, it is the shock of offer which dominates GDP fluctuations $(97 \%$ in Morocco, $82 \%$ in Uruguay and $84 \%$ in the Philippines). Nominal shock plays a significant role in GDP fluctuations, with a share close to 14 $\%$ in Uruguay and $6 \%$ in Philippines. The contribution of the shock of demand is rather limited and does not exceed $8 \%$.

For the real exchange rate, the analysis of the variance decomposition of forecast error indicates that for the three countries the shocks of demand dominate real exchange rate fluctuations, representing $94 \%$ in Morocco, $85 \%$ in the Philippines and $75 \%$ in Uruguay. In second position we find the nominal shock which explains $14 \%$ of the real exchange rate variations in Uruguay and $10 \%$ in the Philippines. However, in Morocco, the contribution of the nominal shock is very low, with a share which does not exceed $4 \%$. The shock of offer has an insignificant effect in Morocco and is limited in Uruguay and in the Philippines, with respective shares of $6 \%$ and $10 \%$. Similarly, the external shock contribution is rather limited with a part which does not exceed $10 \%$.

As expected, most price variations are explained by nominal shocks, with a share of $65 \%$ in Morocco, $54 \%$ in Uruguay and $45 \%$ in the Philippines. The shocks of offer play a relatively important role in price fluctuations, notably in the Philippines and in Uruguay with a share of 35 $\%$. The shock of demand explains a relatively low but significant part of price variations, representing between $14 \%$ in the Philippines and $18 \%$ in Morocco. However the external shock seems to contribute very lowly to price fluctuations, with a share which does not exceed $8 \%$.

These results are compatible with those of Clarida and Gali (1995) and Astley and Garratt (2000) who noticed that for a sample of developed countries real exchange rate fluctuations are generally dominated by the shocks of demand. Besides, Hoffmaister and Roldos (1999) found similar results for a panel of Asian and Latin American countries. Indeed, Hoffmaister and Roldos (1999) considered that GDP fluctuations are completely explained by domestic shocks. Among domestic shocks, it is the shock of offer which is the major source of GDP fluctuations with a share close to $90 \%$ for Asia and $60 \%$ for Latin America, both in the short and long-run. The shock of foreign interest rate only explains $5 \%$ of GDP long-run fluctuations; the short-run effect is low. For Asia they noticed that a large part of real exchange rate fluctuations can be explained by the shock of demand and that the contribution of the external shock is low. The 
contribution of external shocks on the interest rate is, on the other hand, not significant for Latin America.

These results confirm that the variations of the non-tradable goods relative price dominate real exchange rate fluctuations and that the deviation to PPA for tradable goods only plays a small role. The predominance of real shocks which can be explained by the importance of structural changes, implies that the real exchange rate behavior depends on economic specificities. It is the internal dynamics of each economy, the behavior of agents about consumption and investment as well as the way budgetary policy in conducted which explain real exchange rate variations. However, these conclusions do not imply that external and nominal shocks are not potential sources of real exchange rate fluctuations. Impulse response functions clearly indicate that the real exchange rate is also sensitive to nominal and external shocks.

\section{Conclusion}

What are the major sources of real exchange rate fluctuations in developing countries ? It is those questions that we have tackled in this paper in order to underline the relative importance of the different sources of impulsion. Our economic results suggest that domestic shocks dominate real exchange rate fluctuations and that the contribution of external shocks is rather low. These results are in accordance with those of Hoffmaister and Roldos (1999) for developing countries and with those of Froot and Rogoff (1991) for developed countries.

Among domestic shocks the shocks of demand essentially account for real exchange rate variations . However, transitory shocks only lowly contribute to real exchange rate variations both for the short and long-run. It is important to notice that the low contribution of nominal shocks to real exchange rate fluctuations is not altered by the choice of nominal variables. Indeed, we carried out similar exercises of variance decomposition of forecast error by replacing prices by the nominal exchange rate and we came to the same conclusion, i.e. that nominal shocks lowly contribute to real exchange rate variations. This result goes against the models which rest upon nominal shocks to account for real exchange rate fluctuations in developing countries. Besides, the low contribution of the nominal shock calls into question monetary policies which seek to promote competitiveness through currency devaluation. 
If the contribution of external shocks (shocks on the foreign interest rate and on the terms of exchange) is low, it does not imply however that external factors have no role to play in real exchange rate fluctuations. Indeed, the impulse response functions to shocks confirm that the real exchange rate also depends on external shocks and that the shocks on foreign interest rate and/or on the terms of exchange can make it move from its equilibrium level. The budgetary tool therefore remains efficient to stabilize the real exchange rate with respect to possible external shocks.

\section{References}

[1] Astley M. et A. Garratt (2000), "Exchange Rates and Prices : Sources of Sterling Real Exchange Rate Fluctuations 1973-94," International Economic Review, pp 491-509.

[2] Agénor P.R. et P. Montiel, eds (1997), Development Macroeconomics , New Jersey, Princeton University Press.

[3] Agénor P., J. MC Dermott et E. Pradsad (2000), "Macroeconomic Fluctuations in Developing Countries : Some Stylised Facts," World Bank Economic Review, Vol. 14, N², pp 251-87.

[4] Bankim C. et Prasad E. (1997), "Real Exchange Rate and the Business Cycle : Evidence from Japan," IMF Staff Paper, Vol. 44, pp 328-55.Barro (1999), "Notes on Growth Accounting," Journal of Economic Growth, vol 4, ${ }^{\circ} 2$.

[5] Blanchard O. et D. Quah (1989), "The Dynamic Effects of Aggregate Demand and Supply Disturbances," American Economic Review, Vol. 79, pp 655-73.

[6] Bruneau C. et De Brandt O. (1999), "La Modélisation VAR "Structural" Application à la Politique Monétaire Francaise," Economie et Prévision, Vol. 137, pp 67-94.

[7] Clarida R. et J. Gali (1994), "Sources of Real Exchange Rate Fluctuations : How Important are Nominal Shocks?" Carnegie Rochester Conference Series on Public Policy, Vol.41, pp 156.

[8] Elliott B., Rothenberg et Stock J. (1996), "Efficient Tests for an Autoregressive Unit Root," Econometrica, Vol. 64, pp 813-836.

[9] Froot, K. et K. Rogoff (1991), "Government Consumption and the Real Exchange Rate: The Empirical Evidence," mimeo, Harvard Business School.

[10] Giavazzi F. et M. Pagno, (1990), "Can Several Fiscal Contractions be Expansionary? Tales of Two Small European Countries," In NBER Macroeconomic Annueal, edité par O; Blanchard et S; Fisher, pp 75-122, Cambridge, Mass.

[11] Hoffmaister A. et J. Roldos (1997), "Are Business Cycles Different in Asia and Latin America," IMF Working Papers.

[12] Hoffmaister A.W. et J. Roldos (2001), "The Sources of Macroeconomics Fluctuation in Developing Countries : Brasil and Korea," Journal of Monetary Economics, pp 213-239.

[13] Johansen S. et K. Juselius (1990), "Maximum Likelihood and Inference on Cointegration with Applications to the Demand for Money,"Oxford Bulletin of Economics and Statistics, Vol. 52, pp 169-210. 
[14] Johansen S. (1988), "Statistical Analysis of Cointegration Vectors," Journal of Economic Dynamics and Control, vol 12, pp 231-254.

[15] Johansen S. (1992), "Determination of the Cointegration Rank in the Presence of a Linear Trend," Oxford Bulletin of Economics and Statistics, Vol. 54, pp 383-397.

[16] Kamin S. et J. Rogers (1997), Output and the Real Exchange Rate in Developing Countries $\therefore$ An Application to Mexico, Board Governors of the Federal Reserves System, International Finance, Discussion Papers $\mathrm{N}^{\circ} 580$.

[17] Kwiatkoski D., P. Philipps, P. Schmidt et Y. Shin (1992), "Testing the Null Hypothesis of Stationarity Against the Alternative of a Unit Root : How Sure are we that Economic Time Series have a Unit Root? "Journal of Econometrics, Vol. 54, pp 159-178.

[18] Lizondo S. et P. Montiel (1989), "Conctractionary Devaluation in Developing Countries : An Analytical Overview," IMF Staff Papers, Vol. 36, pp 182-227. 


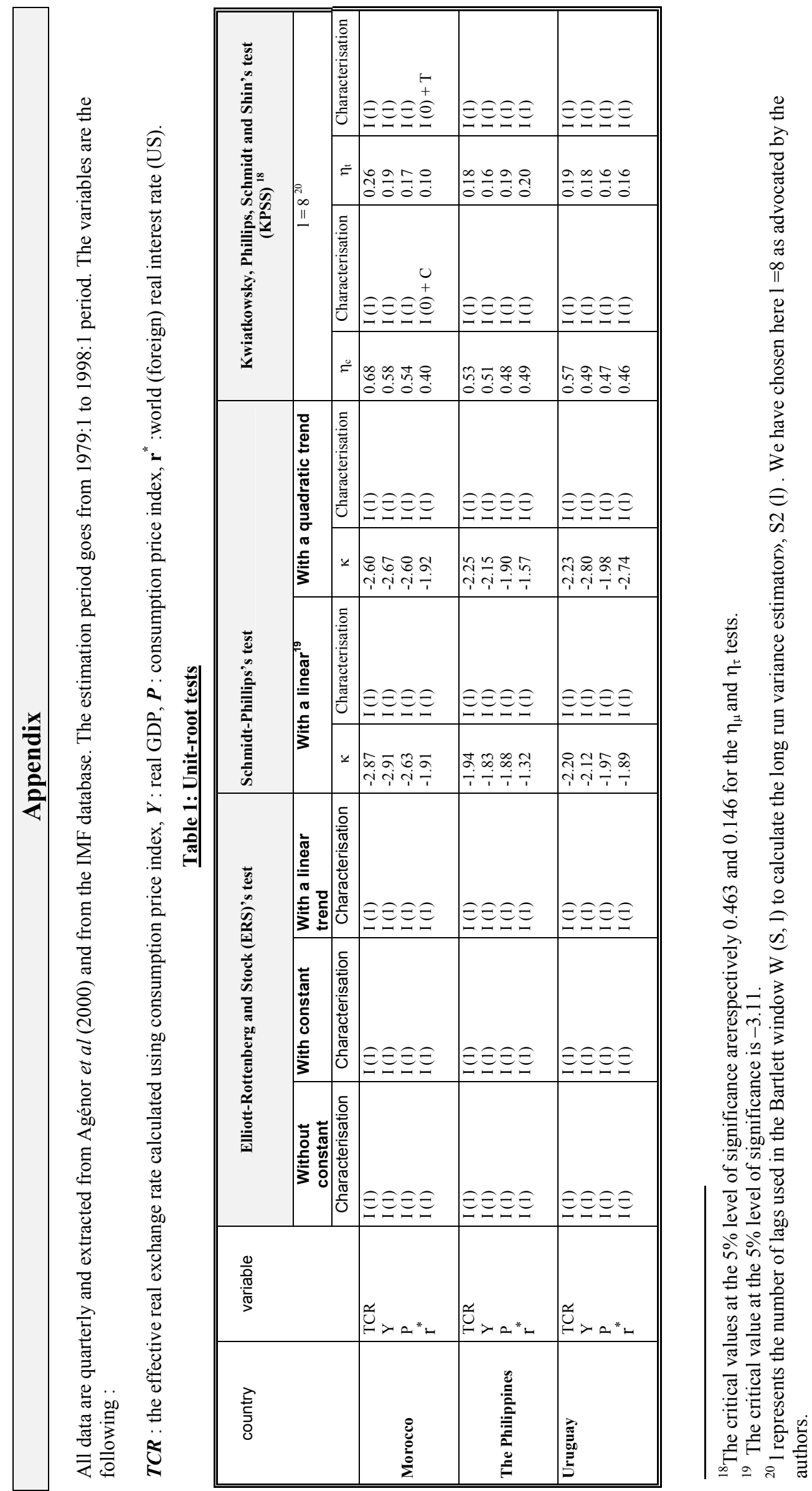


Table 2: Johansen's cointégration tests (1988)

\begin{tabular}{|c|c|c|c|c|c|}
\hline \multirow[b]{2}{*}{$\mathrm{HO}$} & \multicolumn{2}{|l|}{ L_max } & \multicolumn{2}{|l|}{ Trace } & \multirow{2}{*}{$\begin{array}{l}\text { Number of } \\
\text { cointegrating } \\
\text { relationships }\end{array}$} \\
\hline & 0 & 1 & 0 & 1 & \\
\hline Morocco & 11,04 & 2,55 & 13,59 & 2,55 & 0 \\
\hline The Philippines & 5,93 & 2,25 & 8,18 & 2,25 & 0 \\
\hline Uruguay & 10,19 & 6,1 & 16,29 & 6,1 & 0 \\
\hline
\end{tabular}

\section{Figure 1: Impulse response functions}

Morocco
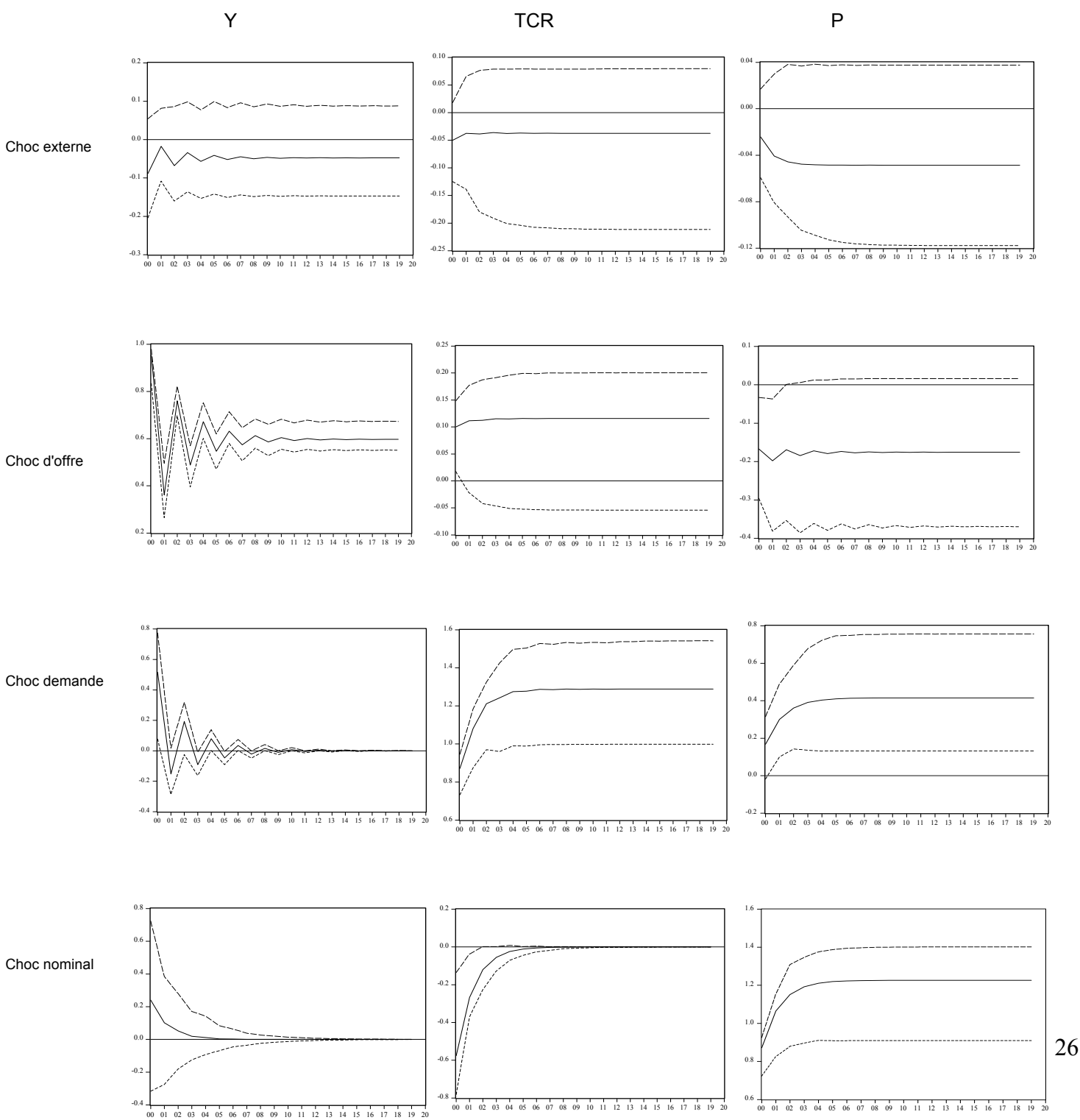
The Philippines
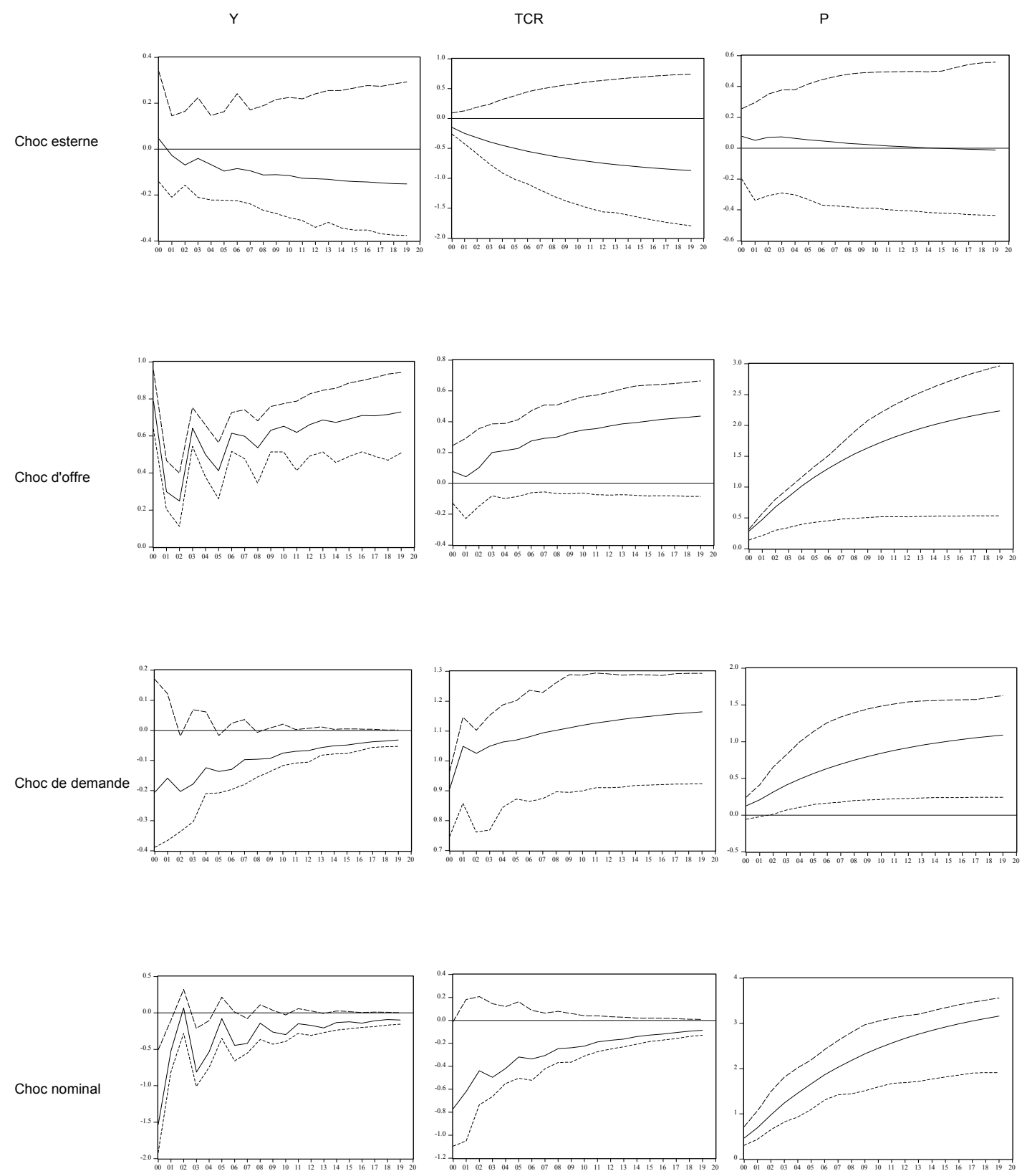


\section{Uruguay}
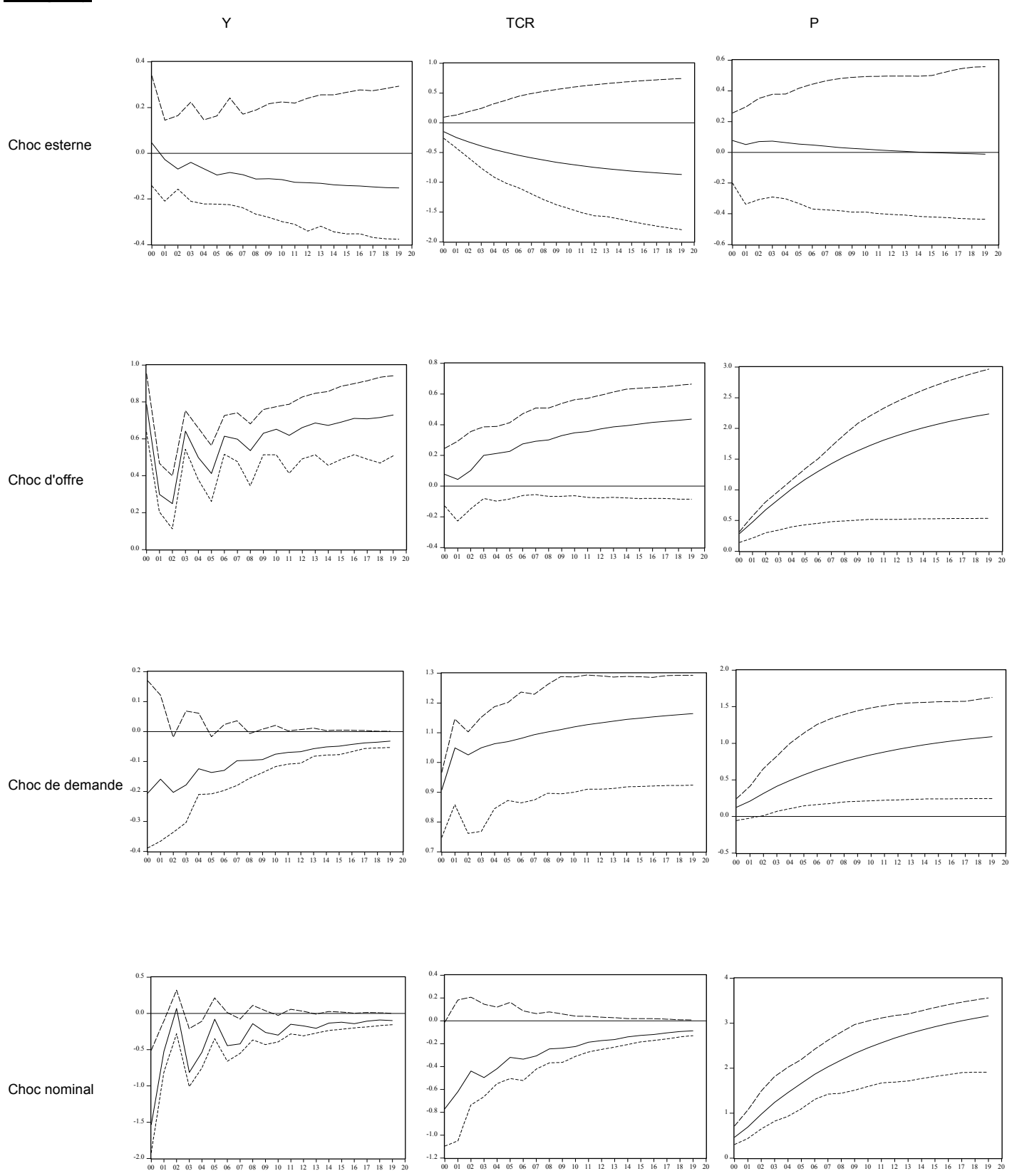
The three tables below report for the three countries the contribution of the 4 shocks (expressed in percentage) to the variance of forecast error of each variable

Table 3: Variance decomposition of forecast error for Morocco

\begin{tabular}{|c|c|c|c|c|c|}
\hline VAR Model ${ }^{21}$ & & (Y TCR, P, R) & & & (Y TCR, P, TCN) \\
\hline \multicolumn{6}{|c|}{ External shock } \\
\hline Periods & GDP & Real exchange rate & Prices & Foreign interest rate ${ }^{22}$ & \multirow{8}{*}{\begin{tabular}{||c} 
Nominal exchange rate \\
$2.60 \%$ \\
$3.20 \%$ \\
$3.50 \%$ \\
$3.60 \%$ \\
$3.58 \%$ \\
$3.58 \%$ \\
$3.58 \%$ \\
\end{tabular}} \\
\hline 1 & $1.73 \%$ & $1.14 \%$ & $1.80 \%$ & & \\
\hline 2 & $1.80 \%$ & $1.63 \%$ & $2.54 \%$ & \multirow{2}{*}{$\begin{array}{l}100 \% \\
100 \%\end{array}$} & \\
\hline 4 & $1.81 \%$ & $2.21 \%$ & $2.47 \%$ & & \\
\hline 8 & $1.81 \%$ & $2.22 \%$ & $2.48 \%$ & $100 \%$ & \\
\hline 12 & $1.81 \%$ & $2.22 \%$ & $2.48 \%$ & $100 \%$ & \\
\hline 16 & $1.81 \%$ & $2.22 \%$ & $2.48 \%$ & \multirow{2}{*}{$\begin{array}{l}100 \% \\
100 \%\end{array}$} & \\
\hline 20 & $1.81 \%$ & $2.22 \%$ & $2.48 \%$ & & \\
\hline \multicolumn{5}{|c|}{ Offer Shock } & \\
\hline 1 & $97.52 \%$ & $1.29 \%$ & $17.06 \%$ & $0 \%$ & $1.80 \%$ \\
\hline 2 & $97.02 \%$ & $1.66 \%$ & $15.61 \%$ & $0 \%$ & $1.70 \%$ \\
\hline 4 & $97.00 \%$ & $1.68 \%$ & $15.08 \%$ & $0 \%$ & $1.80 \%$ \\
\hline 8 & $96.99 \%$ & $1.69 \%$ & $15.04 \%$ & $0 \%$ & $1.81 \%$ \\
\hline 12 & $96.99 \%$ & $1.70 \%$ & $15.04 \%$ & $0 \%$ & $1.82 \%$ \\
\hline 16 & $96.99 \%$ & $1.70 \%$ & $15.04 \%$ & $0 \%$ & $1.82 \%$ \\
\hline 20 & $96.99 \%$ & $1.70 \%$ & $15.04 \%$ & $0 \%$ & $1.82 \%$ \\
\hline \multicolumn{5}{|c|}{ Demand Shock } & \\
\hline 1 & $0.91 \%$ & $95.02 \%$ & $14.79 \%$ & $0 \%$ & $94.00 \%$ \\
\hline 2 & $0.88 \%$ & $94.61 \%$ & $17.10 \%$ & $0 \%$ & $93.00 \%$ \\
\hline 4 & $0.90 \%$ & $94.39 \%$ & $17.87 \%$ & $0 \%$ & $92.90 \%$ \\
\hline 8 & $0.90 \%$ & $94.37 \%$ & $17.93 \%$ & $0 \%$ & $92.80 \%$ \\
\hline 12 & $0.90 \%$ & $94.37 \%$ & $17.93 \%$ & $0 \%$ & $92.80 \%$ \\
\hline 16 & $0.90 \%$ & $94.37 \%$ & $17.93 \%$ & $0 \%$ & $92.80 \%$ \\
\hline 20 & $0.90 \%$ & $94.37 \%$ & $17.93 \%$ & $0 \%$ & $92.80 \%$ \\
\hline \multicolumn{5}{|c|}{ Nominal Shock } & \\
\hline 1 & $0.27 \%$ & $1.69 \%$ & $67.06 \%$ & $0 \%$ & $1.70 \%$ \\
\hline 2 & $0.28 \%$ & $1.71 \%$ & $65.24 \%$ & $0 \%$ & $1.71 \%$ \\
\hline 4 & $0.29 \%$ & $1.71 \%$ & $64.61 \%$ & $0 \%$ & $1.72 \%$ \\
\hline 8 & $0.30 \%$ & $1.71 \%$ & $64.56 \%$ & $0 \%$ & $1.70 \%$ \\
\hline 12 & $0.30 \%$ & $1.71 \%$ & $64.56 \%$ & $0 \%$ & $1.70 \%$ \\
\hline 16 & $0.30 \%$ & $1.71 \%$ & $64.56 \%$ & $0 \%$ & $1.70 \%$ \\
\hline 20 & $0.30 \%$ & $1.71 \%$ & $64.56 \%$ & $0 \%$ & $1.70 \%$ \\
\hline
\end{tabular}

${ }^{21}$ Two VAR models have been estimated here: a first one including the (Y, TCR, P, R) variables and another in which prices have been replaced by the nominal exchange rate (TCN). This permits us to decompose the global effect on the real exchange rate into an effect on domestic prices and an effect on nominal exchange rate.

${ }^{22}$ As foreign real interest rate is supposed to be exogenous (assumption of small country), it is not affected by domestic shocks. 
$\underline{\text { Table } 4 \text { : Variance decomposition of forecast error for Uruguay }}$

\begin{tabular}{|c|c|c|c|c|c|}
\hline VAR Model ${ }^{23}$ & & (Y TCR, P, R) & & & (Y TCR, P, TCN) \\
\hline \multicolumn{6}{|c|}{ External shock } \\
\hline Periods & GDP & Real exchange rate & Prices & Foreign interest rate ${ }^{24}$ & Nominal exchange rate \\
\hline 1 & $0.44 \%$ & $4.04 \%$ & $0.04 \%$ & $100 \%$ & $9.60 \%$ \\
\hline 2 & $0.44 \%$ & $4.01 \%$ & $0.03 \%$ & $100 \%$ & $10.20 \%$ \\
\hline 4 & $0.44 \%$ & $3.98 \%$ & $0.03 \%$ & $100 \%$ & $10.20 \%$ \\
\hline 8 & $0.44 \%$ & $3.96 \%$ & $0.03 \%$ & $100 \%$ & $10.14 \%$ \\
\hline 12 & $0.44 \%$ & $3.95 \%$ & $0.03 \%$ & $100 \%$ & $10.10 \%$ \\
\hline 16 & $0.44 \%$ & $3.95 \%$ & $0.03 \%$ & $100 \%$ & $10.10 \%$ \\
\hline 20 & $0.44 \%$ & $3.95 \%$ & $0.03 \%$ & $100 \%$ & $10.10 \%$ \\
\hline \multicolumn{6}{|c|}{ Offer Shock } \\
\hline 1 & $81.93 \%$ & $6.53 \%$ & $33.48 \%$ & $0 \%$ & $0.60 \%$ \\
\hline 2 & $82.22 \%$ & $7.06 \%$ & $33.57 \%$ & $0 \%$ & $0.60 \%$ \\
\hline 4 & $82.00 \%$ & $7.25 \%$ & $33.81 \%$ & $0 \%$ & $0.90 \%$ \\
\hline 8 & $81.91 \%$ & $7.38 \%$ & $33.91 \%$ & $0 \%$ & $10.70 \%$ \\
\hline 12 & $81.89 \%$ & $7.41 \%$ & $33.92 \%$ & $0 \%$ & $1.08 \%$ \\
\hline 16 & $81.89 \%$ & $7.42 \%$ & $33.92 \%$ & $0 \%$ & $1.08 \%$ \\
\hline 20 & $81.89 \%$ & $7.42 \%$ & $33.92 \%$ & $0 \%$ & $1.08 \%$ \\
\hline \multicolumn{6}{|c|}{ Demand Shock } \\
\hline 1 & $3.32 \%$ & $75.00 \%$ & $12.05 \%$ & $0 \%$ & $79.70 \%$ \\
\hline 2 & $3.26 \%$ & $74.46 \%$ & $13.82 \%$ & $0 \%$ & $78.90 \%$ \\
\hline 4 & $3.32 \%$ & $74.02 \%$ & $15.07 \%$ & $0 \%$ & $78.30 \%$ \\
\hline 8 & $3.35 \%$ & $73.75 \%$ & $15.64 \%$ & $0 \%$ & $77.90 \%$ \\
\hline 12 & $3.35 \%$ & $73.69 \%$ & $15.74 \%$ & $0 \%$ & $77.80 \%$ \\
\hline 16 & $3.35 \%$ & $73.68 \%$ & $15.76 \%$ & $0 \%$ & $77.80 \%$ \\
\hline 20 & $3.35 \%$ & $73.68 \%$ & $15.76 \%$ & $0 \%$ & $77.80 \%$ \\
\hline \multicolumn{6}{|c|}{ Nominal Shock } \\
\hline 1 & $14.32 \%$ & $14.42 \%$ & $54.43 \%$ & $0 \%$ & $10.01 \%$ \\
\hline 2 & $14.08 \%$ & $14.47 \%$ & $52.58 \%$ & $0 \%$ & $10.09 \%$ \\
\hline 4 & $14.25 \%$ & $14.75 \%$ & $51.10 \%$ & $0 \%$ & $10.50 \%$ \\
\hline 8 & $14.31 \%$ & $14.91 \%$ & $50.43 \%$ & $0 \%$ & $10.80 \%$ \\
\hline 12 & $14.32 \%$ & $14.94 \%$ & $50.32 \%$ & $0 \%$ & $10.90 \%$ \\
\hline 16 & $14.32 \%$ & $14.95 \%$ & $50.30 \%$ & $0 \%$ & $10.90 \%$ \\
\hline 20 & $14.32 \%$ & $14.95 \%$ & $50.29 \%$ & $0 \%$ & $10.90 \%$ \\
\hline
\end{tabular}

\footnotetext{
${ }^{23}$ Two VAR models have been estimated here: a first one including the (Y, TCR, P, R) variables and another in which prices have been replaced by the nominal exchange rate (TCN). This permits us to decompose the global effect on the real exchange rate into an effect on domestic prices and an effect on nominal exchange rate.

${ }^{24}$ As foreign real interest rate is supposed to be exogenous (assumption of small country), it is not affected by domestic shocks.
} 
Table 5 : Variance decomposition of forecast error for The Philippines

\begin{tabular}{|c|c|c|c|c|c|}
\hline VAR Model $^{25}$ & & (Y TCR, P, R) & & & (Y TCR, P, TCN) \\
\hline \multicolumn{6}{|c|}{ External shock } \\
\hline Periods & GDP & Real exchange rate & Prices & Foreign interest rate ${ }^{26}$ & \multirow{8}{*}{\begin{tabular}{||c} 
Nominal exchange rate \\
$1.62 \%$ \\
$1.64 \%$ \\
$1.67 \%$ \\
$1.67 \%$ \\
$1.67 \%$ \\
$1.67 \%$ \\
$1.67 \%$ \\
\end{tabular}} \\
\hline 1 & $1.00 \%$ & $0.72 \%$ & $11.03 \%$ & \multirow{7}{*}{$\begin{array}{l}100 \% \\
100 \% \\
100 \% \\
100 \% \\
100 \% \\
100 \% \\
\end{array}$} & \\
\hline 2 & $2.65 \%$ & $0.72 \%$ & $8.91 \%$ & & \\
\hline 4 & $2.95 \%$ & $0.75 \%$ & $8.33 \%$ & & \\
\hline 8 & $2.99 \%$ & $0.76 \%$ & $8.20 \%$ & & \\
\hline 12 & $2.99 \%$ & $0.76 \%$ & $8.20 \%$ & & \\
\hline 16 & $2.99 \%$ & $0.76 \%$ & $8.20 \%$ & & \\
\hline 20 & $2.99 \%$ & $0.76 \%$ & $8.20 \%$ & & \\
\hline \multicolumn{5}{|c|}{ Offer Shock } & \\
\hline 1 & $84.19 \%$ & $13.36 \%$ & $23.65 \%$ & $0 \%$ & $0.40 \%$ \\
\hline 2 & $84.45 \%$ & $13.40 \%$ & $32.20 \%$ & $0 \%$ & $0.50 \%$ \\
\hline 4 & $83.68 \%$ & $13.45 \%$ & $32.66 \%$ & $0 \%$ & $0.50 \%$ \\
\hline 8 & $83.60 \%$ & $13.47 \%$ & $32.77 \%$ & $0 \%$ & $0.60 \%$ \\
\hline 12 & $83.60 \%$ & $13.47 \%$ & $32.78 \%$ & $0 \%$ & $0.60 \%$ \\
\hline 16 & $83.60 \%$ & $13.47 \%$ & $32.78 \%$ & $0 \%$ & $0.60 \%$ \\
\hline 20 & $83.60 \%$ & $13.47 \%$ & $32.78 \%$ & $0 \%$ & $0.60 \%$ \\
\hline \multicolumn{5}{|c|}{ Demand Shock } & \\
\hline 1 & $7.77 \%$ & $85.72 \%$ & $13.76 \%$ & $0 \%$ & $97.80 \%$ \\
\hline 2 & $6.98 \%$ & $85.55 \%$ & $13.22 \%$ & $0 \%$ & $97.70 \%$ \\
\hline 4 & $7.84 \%$ & $85.46 \%$ & $13.92 \%$ & $0 \%$ & $97.60 \%$ \\
\hline 8 & $7.96 \%$ & $85.43 \%$ & $14.00 \%$ & $0 \%$ & $97.60 \%$ \\
\hline 12 & $7.96 \%$ & $85.43 \%$ & $14.00 \%$ & $0 \%$ & $97.60 \%$ \\
\hline 16 & $7.96 \%$ & $85.43 \%$ & $14.00 \%$ & $0 \%$ & $97.60 \%$ \\
\hline 20 & $7.96 \%$ & $85.43 \%$ & $14.00 \%$ & $0 \%$ & $97.60 \%$ \\
\hline \multicolumn{5}{|c|}{ Nominal Shock } & \\
\hline 1 & $7.05 \%$ & $0.21 \%$ & $51.56 \%$ & $0 \%$ & $0.60 \%$ \\
\hline 2 & $5.91 \%$ & $0.34 \%$ & $45.67 \%$ & $0 \%$ & $0.61 \%$ \\
\hline 4 & $5.53 \%$ & $0.34 \%$ & $45.09 \%$ & $0 \%$ & $0.70 \%$ \\
\hline 8 & $5.45 \%$ & $0.35 \%$ & $45.03 \%$ & $0 \%$ & $0.80 \%$ \\
\hline 12 & $5.45 \%$ & $0.35 \%$ & $45.03 \%$ & $0 \%$ & $0.80 \%$ \\
\hline 16 & $5.45 \%$ & $0.35 \%$ & $45.03 \%$ & $0 \%$ & $0.80 \%$ \\
\hline 20 & $5.45 \%$ & $0.35 \%$ & $45.03 \%$ & $0 \%$ & $0.80 \%$ \\
\hline
\end{tabular}

\footnotetext{
${ }^{25}$ Two VAR models have been estimated here: a first one including the (Y, TCR, P, R) variables and another in which prices have been replaced by the nominal exchange rate (TCN). This permits us to decompose the global effect on the real exchange rate into an effect on domestic prices and an effect on nominal exchange rate.

${ }^{26}$ As foreign real interest rate is supposed to be exogenous (assumption of small country), it is not affected by domestic shocks.
} 


\section{DAVIDSON INSTITUTE WORKING PAPER SERIES - Most Recent Papers}

The entire Working Paper Series may be downloaded free of charge at: www.wdi.bus.umich.edu

CURRENT AS OF $2 / 17 / 04$

\begin{tabular}{|c|c|c|}
\hline Publication & Authors & Date \\
\hline $\begin{array}{l}\text { No. 652: Ownership, Control and Corporate Performance After } \\
\text { Large-Scale Privatization }\end{array}$ & $\begin{array}{l}\text { Jan Hanousek, Evzen Kocenda } \\
\text { and Jan Svejnar }\end{array}$ & Feb. 2004 \\
\hline $\begin{array}{l}\text { No. 651: Czech Social Reform/Non-reform: Routes, Actors and } \\
\text { Problems }\end{array}$ & Jiri Vecernik & Feb. 2004 \\
\hline $\begin{array}{l}\text { No. 650: Financial Integration, Exchange Rate Regimes in CEECs, } \\
\text { and Joining the EMU: Just Do It... }\end{array}$ & Maurel Mathilde & Feb. 2004 \\
\hline $\begin{array}{l}\text { No. 649: Corporate Investments, Liquidity and Bank Financing: } \\
\text { Empirical Evidence from an Emerging Market }\end{array}$ & Arun Khanna & Feb. 2004 \\
\hline $\begin{array}{l}\text { No. 648: Financial Constraints in Investment - Foreign Versus } \\
\text { Domestic Firms. Panel Data Results From Estonia, 1995-1999. }\end{array}$ & $\begin{array}{l}\text { Tomasz Mickiewicz, Kate Bishop } \\
\text { and Urmas Varblane }\end{array}$ & Feb. 2004 \\
\hline $\begin{array}{l}\text { No. 647: Legal Minimum Wages and the Wages of Formal and Informal } \\
\text { Sector Workers in Costa Rica }\end{array}$ & $\begin{array}{l}\text { T. H. Gindling and Katherine } \\
\text { Terrell }\end{array}$ & Feb. 2004 \\
\hline $\begin{array}{l}\text { No. 646: Employment Expectations and Gross Flows by Type of Work } \\
\text { Contract }\end{array}$ & $\begin{array}{l}\text { Catalina Amuedo-Dorantes and } \\
\text { Miguel Á. Malo }\end{array}$ & Jan. 2004 \\
\hline $\begin{array}{l}\text { No. 645: Transition on the Shop Floor - The Restructuring of a Weaving } \\
\text { Mill, Hungary 1988-97 }\end{array}$ & János Köllö & Jan. 2004 \\
\hline $\begin{array}{l}\text { No. 644: Fighting "Low Equilibria” by Doubling the Minimum Wage? } \\
\text { Hungary's Experiment }\end{array}$ & Gábor Kertei and János Köllő & Jan. 2004 \\
\hline $\begin{array}{l}\text { No. 643: Mind the Break! Accounting for Changing Patterns of Growth } \\
\text { during Transition }\end{array}$ & Jan Fidrmuc and Ariane Tichit & Jan. 2004 \\
\hline No. 642: The Monetary Approach to Exchange Rates in the CEECs & $\begin{array}{l}\text { Jesús Crespo-Cuaresma, Jarko } \\
\text { Fidrmuc and Ronald MacDonald }\end{array}$ & Jan. 2004 \\
\hline $\begin{array}{l}\text { No. 641: Community Norms and Organizational Practices: The } \\
\text { Legitimization of Wage Arrears in Russia, 1992-1999 }\end{array}$ & $\begin{array}{l}\text { John S. Earle, Andrew Spicer and } \\
\text { Klara Sabirianova Peter }\end{array}$ & Jan. 2004 \\
\hline No. 640: Trust in Transition: Cross Country and Firm Evidence & $\begin{array}{l}\text { Martin Raiser, Alan Rousso, and } \\
\text { Franklin Steves }\end{array}$ & Jan. 2004 \\
\hline $\begin{array}{l}\text { No. 639: What Makes Small Firms Grow? Finance, Human Capital, } \\
\text { Technical Assistance, and the Business Environment in Romania }\end{array}$ & $\begin{array}{l}\text { J. David Brown, John S. Earle } \\
\text { and Dana Lup }\end{array}$ & Jan. 2004 \\
\hline $\begin{array}{l}\text { No. 638: The Politics of Economic Reform in Thailand: Crisis and } \\
\text { Compromise }\end{array}$ & Allen Hicken & Jan. 2004 \\
\hline $\begin{array}{l}\text { No. 637: How Much Restructuring did the Transition Countries } \\
\text { Experience? Evidence from Quality of their Exports }\end{array}$ & Yener Kandogan & Jan. 2004 \\
\hline $\begin{array}{l}\text { No. 636: Estimating the Size and Growth of Unrecorded Economic } \\
\text { Activity in Transition Countries: A Re-Evaluation of Eclectric } \\
\text { Consumption Method Estimates and their Implications }\end{array}$ & Edgar L. Feige and Ivana Urban & Dec. 2003 \\
\hline No. 635: Measuring the Value Added by Money & Vlad Ivanenko & Nov. 2003 \\
\hline $\begin{array}{l}\text { No. 634: Sensitivity of the Exporting Economy on the External Shocks: } \\
\text { Evidence from Slovene Firms }\end{array}$ & $\begin{array}{l}\text { Janez Prašnikar, Velimir Bole, } \\
\text { Aleš Ahcan and Matjaž Koman }\end{array}$ & Nov. 2003 \\
\hline $\begin{array}{l}\text { No. 633: Reputation Flows: Contractual Disputes and the Channels for } \\
\text { Inter-firm Communication }\end{array}$ & William Pyle & Nov. 2003 \\
\hline $\begin{array}{l}\text { No. 632: The Politics of Development Policy and Development Policy } \\
\text { Reform in New Order Indonesia }\end{array}$ & Michael T. Rock & Nov. 2003 \\
\hline $\begin{array}{l}\text { No. 631: The Reorientation of Transition Countries' Exports: } \\
\text { Changes in Quantity, Quality and Variety }\end{array}$ & Yener Kandogan & Nov. 2003 \\
\hline $\begin{array}{l}\text { No. 630: Inequality of Outcomes and Inequality of Opportunities in } \\
\text { Brazil }\end{array}$ & $\begin{array}{l}\text { François Bourguignon, Francisco } \\
\text { H.G. Ferreira and Marta } \\
\text { Menéndez }\end{array}$ & Nov. 2003 \\
\hline No. 629: Job Search Behavior of Unemployed in Russia & Natalia Smirnova & Nov. 2003 \\
\hline $\begin{array}{l}\text { No. 628: How has Economic Restructuring Affected China's Urban } \\
\text { Workers? }\end{array}$ & John Giles, Albert Park, Feng Cai & Oct. 2003 \\
\hline No. 627: The Life Cycle of Government Ownership & Jiahua Che & Oct. 2003 \\
\hline $\begin{array}{l}\text { No. 626: Blocked Transition And Post-Socialist Transformation: Siberia } \\
\text { in the Nineties }\end{array}$ & Silvano Bolcic & Oct. 2003 \\
\hline
\end{tabular}

